\title{
Socioeconomic status and risk factors for cardiovascular disease (CVD) among the residents of Jammu Division (J\&K-India) - A Geo Medical Analysis
}

\author{
Sheraz Ah. Lone, M. Sabar, Ishtiaq Ah. Mayer \\ Department of Geography, University of Kashmir, Hazaratbal, Srinagar, Jammu and Kashmir [190006], India
}

\begin{abstract}
The main focus of this paper is to examine the relationship between CVD risk factors and socioeconomic variables in Jammu division of Jammu and Kashmir. Cardiovascular disease (CVD) related deaths is not only the prime cause of mortality in the world, it has also continued to increase in the low and middle income countries. The study area was divided into ten districts (administrative units) in GIS environment. linear regression, binary logistic regression model, Kendal's ranking coefficient method were employed to show the incidence, spatial variation and impact of different socioeconomic variables on CVD. The results reveals that the incidence of CVD has increased by 7.31 percent from 2008 to 2016. Samba district was having maximum change of incidence (33.24 percent), however, negative change in incidence rate was found in Udhampur district (-2.41 percent). Consumption of tobacco and alcohol are significant related to cardiovascular diseases.
\end{abstract}

Keywords: CVD, Jammu, Socioeconomic, Vulnerability

\section{Introduction}

Cardiovascular diseases (CVDs) include disorders of heart and blood vessels, and are usually associated with atherosclerosis, heart attacks, strokes, valvular diseases, congenital heart diseases and arrhythmia [1]. Mortality resulting from CVDs reached 17.7 million globally in 2015 , which represented $31 \%$ of all global deaths. Of the CVD deaths, more than three quarters took place in low- and middleincome countries (LMICs) [2]. Cardiovascular diseases, which are typically viewed as diseases of the wealthy, have dramatically infiltrated those living in abject poverty in LMICs [3]. Diseases are intimately related with the socioeconomic environment [4]. Different diseases have varied causes which have their roots in the social and economic domains of the societies or areas [5]. Cardiovascular disease (CVD) is the main cause of death in the world $[6,7]$. However, whereas the adult CVD death rate in developed economies has declined since the 1970's [8] it has risen in the low and middle income countries [9]. Low and middle income countries contributed the highest percentage of CVD deaths worldwide, which rose from 14.4 million in 1990 to 16.5 million in 2005 [10]. Cardiovascular disease (CVD) is no longer limited to developed countries, it is widespread in developing countries $[11,12]$ and the rate of increase in CVD in developing countries is twice as high as in developed countries [13] (Gaziano, 2005). CVD occurs at a younger age in developing countries, about 52 per cent of deaths from such disorders in India occur before 70 year of age, compared with 23 per cent in establishedmarket economies [14]. In the context of this large and growing disease burden, strategies to improve population health in India require consistent efforts to identify and address the real causes of this rapid rise in CVD [15]. In developed countries socio-economic mortality differentials have been studied extensively showing that the low socio-economic group 
suffer the highest mortality [16,17]. Such a trend was not observed for CVD in India until the 1990s, and CVD was regarded as a disease of the affluent classes [18]. The epidemic of CVD struck the more affluent sections of India first, but as the epidemic is maturing, we are observing a graded reversal of social gradient, with socio-economically disadvantaged groups becoming increasingly vulnerable to CVD. For example, the social class gradient in cardiovascular event rates among Indians has reversed with evidence for excess CVD events among the lower socio-economic groups $[19,20]$.In 45 rural villages in India, 32 per cent of all deaths were due to CVD, outranking infectious diseases, which were responsible for 13 per cent giving clear evidence that the epidemic has reached its advanced stage even in rural India [21]. Neglect of this epidemic, particularly ignoring the socio-economic context as they are driven by social and economic changes with lack of an adequate public health response will further fuel the inequities associated with CVD in Indians [22]. Socio-economic mortality differentials have been demonstrated using several indicators of social position representing occupational, educational, and financial aspects [23].

Cardiovascular disease (CVD) is a general term that describes a disease of the heart or blood vessels, and includes coronary heart disease (heart attacks), cerebrovascular disease (stroke), raised blood pressure (hypertension), peripheral artery disease, rheumatic heart disease, congenital heart disease and heart failure [24]. The major causes of cardiovascular disease (CVD) are tobacco use, physical inactivity, an unhealthy diet and harmful use of alcohol [25]. These diseases are epidemic in urban locations of these countries and are rapidly increasing in rural areas as well [26]. Socioeconomic circumstances seriously affect health and wellbeing, making health inequalities a major public health concern around the world. This can be seen in the simple statistic that richer countries tend to have better average health than poorer ones [27]. Although no consistent association has been found between Gross
Domestic Product (GDP) and life expectancy amongst richer countries, several studies have found that within richer countries lower socioeconomic status is associated with poorer health $[28,29,30,31]$. The same tends to be true for individuals in poorer countries and regions of the world, although the evidencebase is not as broad [32] and is often derived from ecological studies that compare average levels of wealth and health in countries [33]. An exciting field of current research studies whether environmental or psychosocial factors such as stress, affect the onset of disease and investigates the complex interactions linking the body'smajor control and sensory systems in health and disease. NIM also investigates how psychosocial factors influence the endocrine system [34]. Accumulating evidence underlines the major rolen of chronic stress in accumulating visceral fat, secondary to altered eating behaviors $[35,36]$ Increased abdominal obesity predisposes to the metabolic syndrome, diabetes and cardiovascular diseases (CVD) [37]. The socio-economic scenario of the study area has large degree disparities affecting health of the people accordingly.

\section{Study Area}

Jammu division is situated in the northwestern part of India and lies between $32^{\circ} 17^{\prime}$ to $34^{\circ} 12^{\prime}$ north latitudes and $73^{\circ} 58^{\prime}$ to $76^{\circ} 47^{\prime}$ East longitudes. It covers an area of 26,293 square kilometers which is more than one half times to that of Kashmir division and around $1 / 8^{\text {th }}$ of the total area of the state of Jammu and Kashmir (Census 2011). The division is bounded by the Kashmir Division in the north, by Kargil district of Ladakh division in the north-east. In the south-east it adjoins the Chamba district of Himachal Pradesh. In the south it is bordered by the Gurdaspur district of Punjab, while on the west it is the bounded by Pakistan and territory of Pakistan occupied Kashmir. The Jammu division comprised of 10 districts namely, Rajouri, Poonch, Jammu, Samba, Kathua, Udhampur, Ramban, Reasi, Doda and Kishtwar (image 1). 


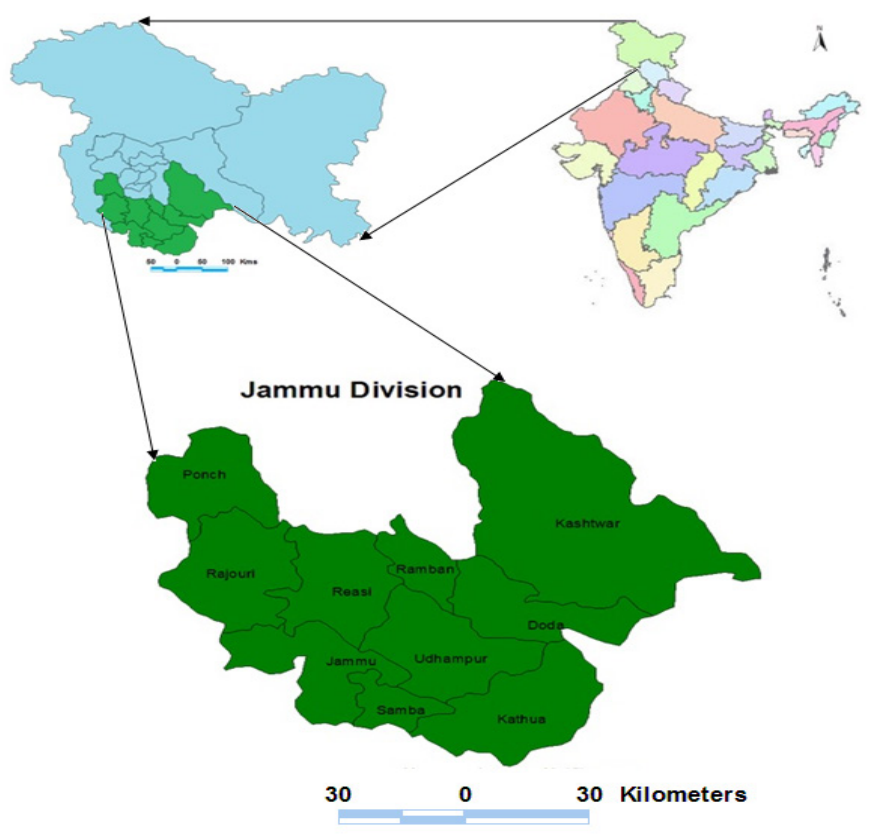

Image 1. Location of the Study Area

\section{Materials and methods}

In order to work out the spatial variation in the distribution of disease Patten area across diffrent districts in the study, data was collected from hospitals/district surviellence offices falling in each district and also from chief medical officers office and block medical officers office. In order to gauge out the incidence of diseases in the study area, data was collected from hospitals, dispensaries and other relevant institutions. Apart from this primary survey was also carried out in all the sample villages.

\subsection{Calculation of Incidence Rate}

In the present study the incidence rate of selected communicable and non-communicable of diseases sex wise has been calculated for five years by using the following formula:

\subsection{Correlation of socio-economic Parameters and diseases}

In simple linear regression, the model used to describe the relationship between a single dependent variable $y$ and a single independent variable $\mathrm{x}$ is

$$
y=a_{0}+a_{1} x+k
$$

$\mathrm{a}_{0}$ and $\mathrm{a}_{1}$ are referred to as the model parameters, and is a probabilistic error term that accounts for the variability in $y$ that cannot be explained by the linear relationship with $\mathrm{x}$. The formulas used in correlation and regression analysis are;

$$
r=\frac{\sum d_{x} d_{y}}{\sqrt{\left(\sum d_{x}^{2} \sum d_{y}^{2}\right)}}
$$

(i) Coefficient of Correlation,

(ii) The Linear Regression equation for $y$ on $x$ is; $\mathrm{Y}=\mathrm{a}+\mathrm{b} x$, where ' $\mathrm{b}$ ' is the slope and ' $\mathrm{a}$ ' is the intercept (the point where the line crosses the Y-axis); $\mathbf{a}=\mathbf{y}$ - $\mathbf{b} \boldsymbol{x}$ and

$$
b=\frac{\sum d_{x} d_{y}}{\sum d_{x}^{2}}
$$

\section{Results and Discussion}

The distribution and incidence of cardiovascular diseases is uneven across the districts of the Jammu division. From table 1, it is clear that the incidence of cardiovascular diseases has increased in all the districts of Jammu division with few exceptions (image 2). In the Jammu province, the incidence rate of cardiovascular diseases has increased from 28.93 persons/1000 to 31.26 persons/1000 of

$\mathrm{IR}=\frac{\text { Number of newcase ofa diseas during a given time period }}{\text { Total population at Risk during the same period of time }} \times 1000$ 
population (Table 1). Jammu has the maximum rate of incidence (42.78 persons/1000), followed by Samba (36.72 persons/1000), and Kathua (36.59 persons/1000). The minimum incidence rate is observed in Ramban district
(17.68 persons/1000); followed by Kishtwar (17.68 persons/1000) and Doda (22.38 persons/1000). The incidence rate is depicted in image 3 and image 4 .

Table 1. Incidence rate of Cardiovascular Diseases in Jammu Division (2008-2012)

\begin{tabular}{|c|c|c|c|c|c|c|c|c|c|c|c|c|c|c|c|c|}
\hline \multirow[t]{3}{*}{ District } & \multicolumn{15}{|c|}{ Incidence rate of Cardiovascular Diseases per 1000 Persons } & \multirow{3}{*}{ 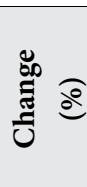 } \\
\hline & \multicolumn{3}{|c|}{2008} & \multicolumn{3}{|c|}{2010} & \multicolumn{3}{|c|}{2012} & \multicolumn{3}{|c|}{2014} & \multicolumn{3}{|c|}{2016} & \\
\hline & $\mathbf{M}$ & $\mathbf{F}$ & $\mathbf{T}$ & $\mathbf{M}$ & $\mathbf{F}$ & $\mathbf{T}$ & $\mathbf{M}$ & $\mathbf{F}$ & $\mathbf{T}$ & $\mathbf{M}$ & $\mathbf{F}$ & $\mathbf{T}$ & $\mathbf{M}$ & $\mathbf{F}$ & $\mathbf{T}$ & \\
\hline Rajouri & 20.97 & 24.23 & 22.48 & 21.98 & 23.93 & 22.88 & 20.94 & 23.26 & 22.01 & 23.95 & 25.9 & 24.85 & 22.98 & 24.82 & 23.83 & 6.01 \\
\hline Poonch & 20.6 & 23.18 & 21.76 & 23.67 & 21.7 & 22.74 & 25.78 & 25.21 & 25.51 & 24.83 & 22.47 & 23.72 & 26.37 & 24.4 & 25.44 & 16.91 \\
\hline Jammu & 45.15 & 40.15 & 42.82 & 43.38 & 43.97 & 43.66 & 45.55 & 40.78 & 43.32 & 44.07 & 41.71 & 42.97 & 44.96 & 40.28 & 42.78 & -0.09 \\
\hline Samba & 24.81 & 30.65 & 27.56 & 25.73 & 31.78 & 28.58 & 24.67 & 34.66 & 29.36 & 28.3 & 37.34 & 32.55 & 38.36 & 34.89 & 36.72 & 33.24 \\
\hline Kathua & 27.88 & 28.5 & 28.18 & 29.87 & 29.96 & 29.91 & 3.71 & 64.83 & 32.84 & 36.01 & 33.81 & 34.98 & 37.15 & 35.95 & 36.59 & 29.84 \\
\hline Reasi & 17.67 & 21.4 & 19.42 & 22.8 & 18.52 & 20.79 & 25.77 & 15.52 & 20.95 & 21.88 & 22.43 & 22.14 & 25.08 & 25.42 & 25.24 & 29.97 \\
\hline Udhampur & 25.95 & 28.37 & 27.07 & 26.48 & 28.98 & 27.64 & 26.27 & 28.67 & 27.39 & 26.59 & 26.98 & 26.77 & 26.81 & 26.14 & 26.49 & -2.14 \\
\hline Doda & 22.26 & 24.35 & 23.86 & 23.64 & 25.76 & 24.65 & 22.87 & 24.09 & 23.45 & 23.75 & 23.81 & 23.78 & 22.33 & 22.44 & 22.38 & -6.20 \\
\hline Ramban & 16.84 & 18.84 & 17.78 & 16.19 & 17.77 & 16.94 & 14.51 & 13.92 & 14.23 & 16.62 & 13.96 & 15.36 & 19.42 & 15.73 & 17.68 & -0.56 \\
\hline Kishtwar & 13.52 & 17.28 & 15.32 & 16.59 & 15.53 & 16.08 & 17.13 & 14.93 & 16.07 & 21.97 & 12.41 & 17.39 & 21.66 & 16.47 & 19.17 & 25.13 \\
\hline Total & 28.93 & 29.34 & 29.13 & 29.57 & 24.29 & 29.91 & 27.21 & 33.24 & 30.04 & 31.08 & 30.18 & 30.66 & 32.27 & 30.12 & 31.26 & 7.31 \\
\hline
\end{tabular}

Source: Directorate of Health, J\&K.

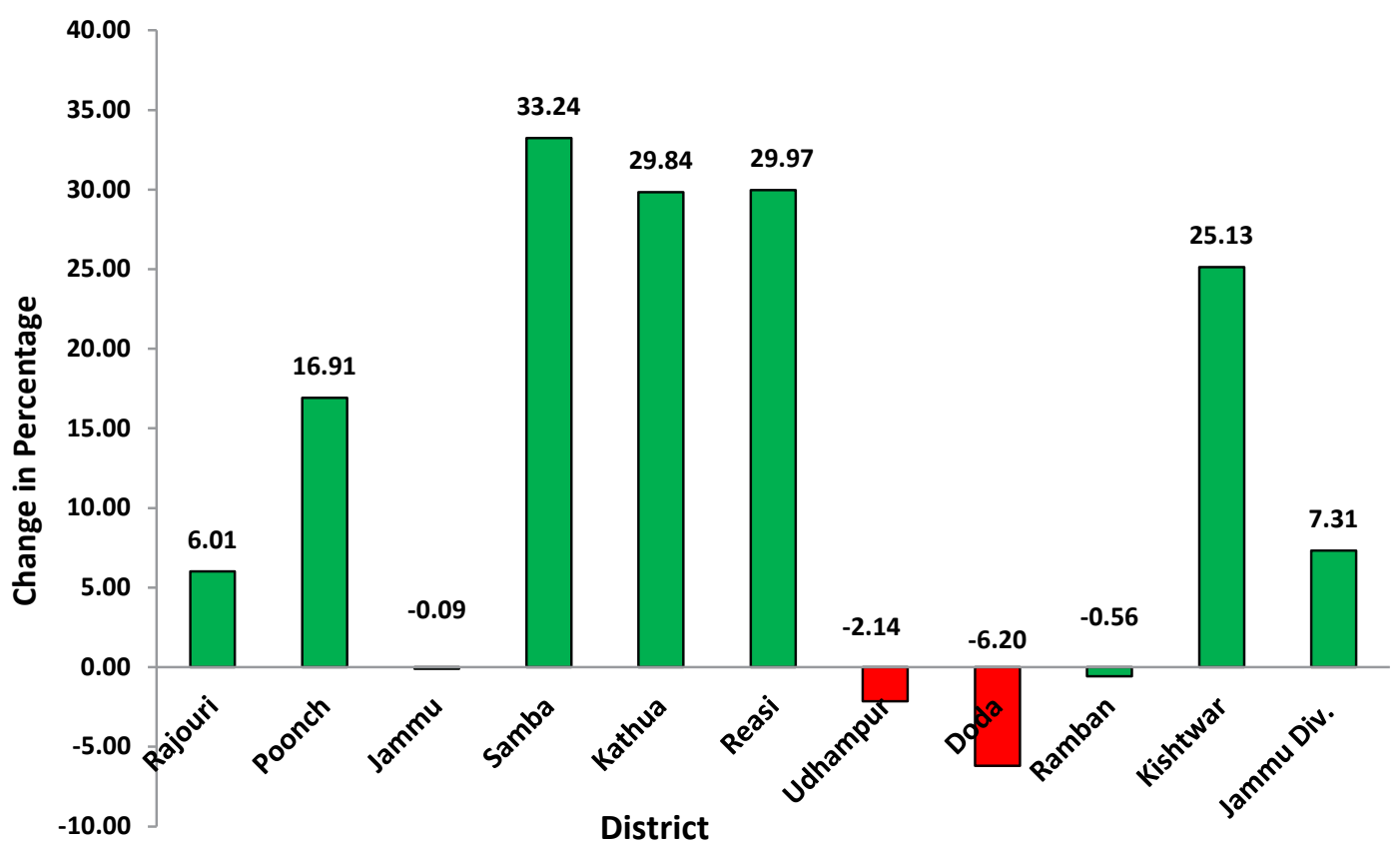

Image 2. change of the incidence rate of Cardiovascular Diseases 


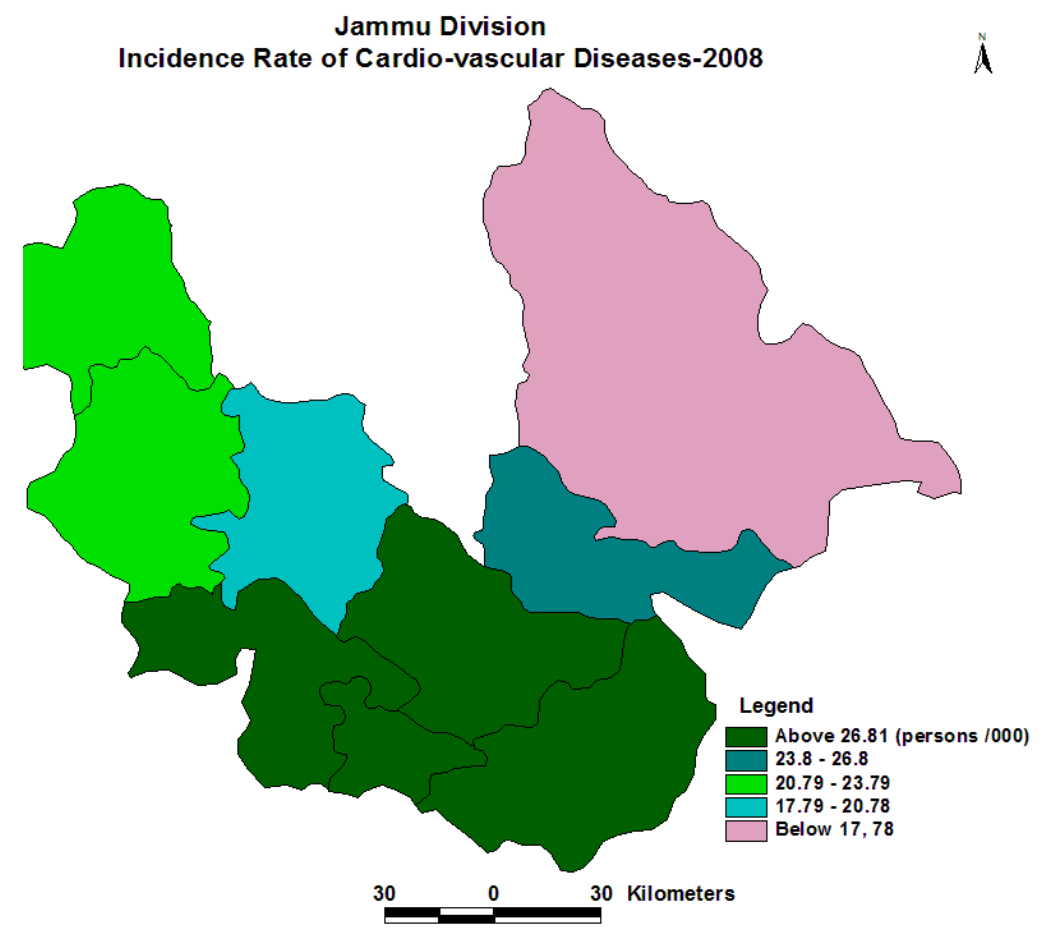

Image 3. incidence rate of Cardiovascular Diseases-2008

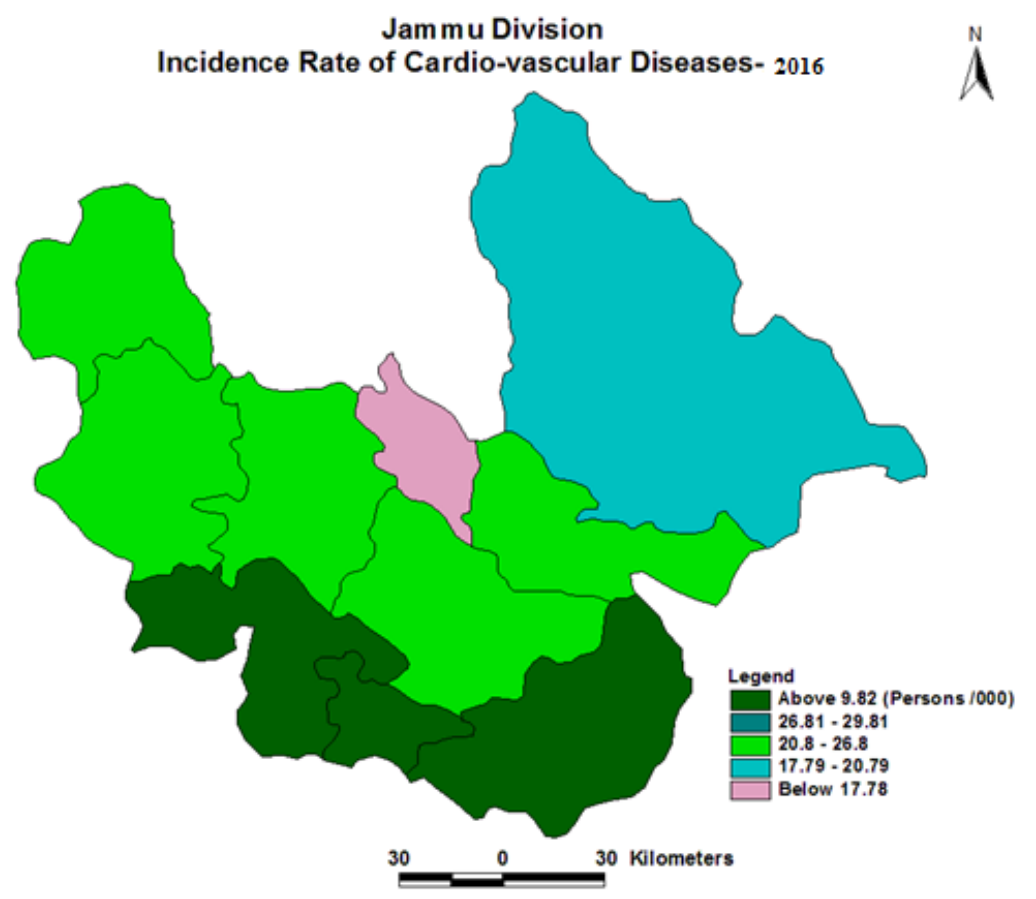

Image 4. incidence rate of Cardiovascular Diseases-2016 
Table 2. Relationship between Socio-economic Factors and Cardiovascular Diseases (CVD) in Jammu division

\begin{tabular}{|c|c|c|c|c|c|c|}
\hline $\begin{array}{l}\text { Socio-economic } \\
\text { Variables }\end{array}$ & $\begin{array}{l}\text { Total } \\
\text { Respondent }\end{array}$ & $\begin{array}{l}\text { Prevalence of } \\
\text { Cardiovascular }\end{array}$ & Odds ratio & Standard Error & Z Value & $\begin{array}{l}\text { Level of } \\
\text { Significance } \\
\text { (P Value) }\end{array}$ \\
\hline \multicolumn{7}{|l|}{ Residence } \\
\hline Rural & 546 & $85(15.6)$ & \multirow{3}{*}{0.204897} & \multirow{3}{*}{0.088662} & \multirow{3}{*}{3.66} & \multirow{3}{*}{00.00} \\
\hline Urban & 204 & 65 (31.9) & & & & \\
\hline Total & 750 & $120(20.0)$ & & & & \\
\hline \multicolumn{7}{|l|}{ Religion } \\
\hline Hindu & 313 & $59(18.8)$ & \multirow{4}{*}{1.144864} & \multirow{4}{*}{0.254359} & \multirow{4}{*}{0.61} & \multirow{4}{*}{0.543} \\
\hline Muslim & 309 & $65(21)$ & & & & \\
\hline Sikh & 128 & $26(20.3)$ & & & & \\
\hline Total & 750 & $120(20.0)$ & & & & \\
\hline \multicolumn{7}{|l|}{ Caste } \\
\hline Upper & 436 & 54 (12.4) & \multirow{3}{*}{0.546678} & \multirow{3}{*}{0.160136} & & \\
\hline Lower & 314 & $96(30.6)$ & & & -2.06 & 0.05 \\
\hline Total & 750 & $120(20.0)$ & & & & \\
\hline Sex & & & & & & \\
\hline Male & 460 & $90(19.6)$ & & & & \\
\hline Female & 290 & $60(20.7)$ & 1.505817 & 0.428429 & 1.44 & 0.15 \\
\hline Total & 750 & $150(20.0)$ & & & & \\
\hline Age & & & & & & \\
\hline $0-6$ & 130 & $0(0)$ & & & & \\
\hline 7_14 & 168 & $15(8.9)$ & & & & \\
\hline $15-59$ & 311 & $91(29.3)$ & 0.42117 & 0.364533 & 4.38 & 0.001 \\
\hline$>60$ & 141 & $44(31.2)$ & & & & \\
\hline Total & 750 & $150(20.0)$ & & & & \\
\hline Education & & & & & & \\
\hline Illiterate & 218 & $22(10.1)$ & & & & \\
\hline Primary & 182 & $26(14.3)$ & & & & \\
\hline Middle & 73 & $16(21.9)$ & & & & \\
\hline Secondary & 145 & $41(28.3)$ & .20749 & 0.167723 & 1.36 & 0.017 \\
\hline Graduation & 92 & $26(28.3)$ & & & & \\
\hline P.G \& Above & 40 & $19(47.5)$ & & & & \\
\hline Total & 750 & $150(20.0)$ & & & & \\
\hline Occupation & & & & & & \\
\hline Primary & 312 & $32(10.26)$ & & & & \\
\hline Secondary & 245 & $50(20.41)$ & 044567 & 0174832 & & 0003 \\
\hline Tertiary & 193 & $68(35.23)$ & 0.44567 & 0.174833 & -2.06 & 00.03 \\
\hline Total & 750 & $150(20.0)$ & & & & \\
\hline Income & & & & & & \\
\hline$<7000$ & 271 & $27(10)$ & & & & \\
\hline $7000-14000$ & 206 & $32(15.5)$ & & & & \\
\hline $15000-22000$ & 100 & $24(24)$ & 200048 & 0416032 & & 0000 \\
\hline $23000-29000$ & 70 & $22(31.4)$ & .290048 & 0.416032 & 4.26 & 00.00 \\
\hline$>30000$ & 103 & $45(43.7)$ & & & & \\
\hline Total & 750 & $150(20.0)$ & & & & \\
\hline House Type & & & & & & \\
\hline Kachha & 423 & $56(13.2)$ & & & & \\
\hline Pucca & 327 & 94 (28.7) & .15959 & 2.061227 & 2.94 & 0.003 \\
\hline Total & 750 & $150(20.0)$ & & & & \\
\hline Toilet & & & & & & \\
\hline Yes & 295 & $90(30.5)$ & & & & \\
\hline No & 455 & $60(13.2)$ & 1.21311 & 0.51759 & 0.46 & 0.645 \\
\hline Total & 750 & $150(20.0)$ & & & & \\
\hline Separate Kitchen & & & & & & \\
\hline Yes & 227 & $40(17.6)$ & & & & \\
\hline No & 523 & $110(21)$ & 0.346076 & 0.17036 & -2.16 & 0.031 \\
\hline Total & 750 & $150(20.0)$ & & & & \\
\hline Tobacco & & & & & & \\
\hline Yes & 286 & $65(22.7)$ & & & & \\
\hline No & 464 & $85(18.3)$ & 1.324387 & 0.492827 & 1.6 & 0.011 \\
\hline Total & 750 & $150(20.0)$ & & & & \\
\hline Alcohol & & & & & & \\
\hline Yes & 264 & $62(23.5)$ & & & & \\
\hline No & 486 & $88(18.1)$ & 1.461434 & 0.40569 & 1.37 & 0.017 \\
\hline Total & 750 & $150(20.0)$ & & & & \\
\hline & & cons & 0.02733 & 0.030559 & -3.22 & 0.001 \\
\hline $\begin{array}{c}\text { log likelihood }=- \\
-228.35639\end{array}$ & $\mathrm{~N}=\mathbf{7 5 0}$ & $\begin{array}{c}\text { LR chi2(13) } \\
85.65\end{array}$ & Psedu & R2 0.1579 & & i2 .0043 \\
\hline
\end{tabular}

Source: Based on field study, 2015 


\subsection{Relationship between Socio-economic Status and Cardiovascular Diseases (CVD)}

Prevalence of cardiovascular diseases in the rural population (15.6 percent) is lower than the urban population (31.9 percent) (table 2). Residence has a Positive impact on CVD. As there is change in residence from rural area to urban by one percentage points, the percentage of people having CVD increase (odd ratio $0.204897)$. Same is the case with occupation (odd ratio 0.44567 ), education (odd ratio 0.20749) and income (odd ratio 0.290048) of the respondents. As there is structural transformation from primary to secondary and tertiary sector, the percentage of people having chances of CVD increase. Likewise as educational standard and level of income of the respondent's increases, the chances of CVD increase. The variable age is significant and positive which means that as the age of respondent increases there are 42 percent chances of increase in CVD. Consumption of tobacco and alcohol are significant related to cardiovascular diseases. Table 2, further indicates that a urban population $(\mathrm{P}=0.00)$, old age $(\mathrm{p}=0.00)$, high income $(\mathrm{p}=0.00)$ better education level $(\mathrm{P}=0.017)$, lives in pacca houses $(P=0.003)$, and consumption of more tobacco $(\mathrm{p}=0.011)$ and alcohol $(\mathrm{p}=0.017)$ were significant independent predictive risk factors for the prevalence of cardiovascular diseases.

\section{Conclusion}

The study highlights that the distribution and incidence of cardiovascular diseases is uneven across the districts of the Jammu division. The incidence rate of cardiovascular diseases has increased from 29.13 persons/ 1000 to 31.26 persons $/ 1000$ of population from 2008 to 2016. The study further reveals the relationship between different Socio-economic Status and Cardiovascular Diseases in the study area. Health promotion strategies such as community-based awareness activities on how to reduce behavioral risk factors of CVDs and appropriate counseling regarding cardiovascular risk reduction ought to be routinely performed. Furthermore, interventional studies should be considered to reduce risky associated with CVDs.

Conflict of Interest: The authors are not having any conflict of interest to the previous studies.

Funding Source: The present research work is not funded by any agency.

Ethical approval: This is to state that this is our original research work and is not under consideration for publication elsewhere, and that its publication in the present form has been approved by all authors.

\section{References}

1. Paudel R, Lee K, Singh JK, Yoo SJ, Acharya D, Kadel R, Adhikari S, Paudel M, Mahotra N. Prevalence of behavioral risk factors of cardiovascular diseases and associated socio-economic factors among pregnant women in a rural area in Southern Nepal. BMC pregnancy and childbirth. 2018 Dec;18(1):1-9.

2. Ruan Y, Guo Y, Zheng Y, Huang Z, Sun S, Kowal P, Shi Y, Wu F. Cardiovascular disease (CVD) and associated risk factors among older adults in six lowand middle-income countries: results from SAGE Wave 1. BMC public health. 2018 Dec;18(1):1-3.

3. Mendis S, Puska P, Norrving B, World Health Organization. Global atlas on cardiovascular disease prevention and control. World Health Organization; 2011.

4. Thys E, Oueadraogo M, Speybroeck N, Geerts S. Socio-economic determinants of urban household livestock keeping in semi-arid Western Africa. Journal of Arid Environments. 2005 Oct 1;63(2):47596.

5. Lone SA, Wani MA, Lone BA, Mayer IA. Spatial pattern of health and health care facilities in District Anantnag of South Kashmir (J\&K, India) - A geo medical analysis. International Journal of Health Sciences and Research. 2017;7(8):358-63.

6. Artham SM, Lavie CJ, Milani RV, Ventura HO. Obesity and hypertension, heart failure, and coronary heart disease-risk factor, paradox, and 
recommendations for weight loss. Ochsner Journal. 2009 Sep 21;9(3):124-32.

7. Smith, G. N., Walker, M. C., Liu, A., Wen, S. W., Swansburg, M., Ramshaw, H \& Hladunewich, M. (2010) A history of preeclampsia identifies women who have underlying cardiovascular risk factors. American Journal of Obstetrics \& Gynecology 200 (1): 58-e1 https://doi.org/10.1016/j. ajog.2008.06.035

8. Jemal A, Center MM, DeSantis C, Ward EM. Global patterns of cancer incidence and mortality rates and trends. Cancer Epidemiology and Prevention Biomarkers. 2010 Aug 1;19(8):1893-907.

9. Gaziano TA, Bitton A, Anand S, Abrahams-Gessel S, Murphy A. Growing epidemic of coronary heart disease in low-and middle-income countries. Current problems in cardiology. $2010 \mathrm{Feb}$ 1;35(2):72-115.

10. Mathers CD, Loncar D. PLoS Med. 3 (11), e442 (2006).

11. McCormack VA, Boffetta P. Today's lifestyles, tomorrow's cancers: trends in lifestyle risk factors for cancer in low-and middle-income countries. Annals of Oncology. 2011 Nov 1;22(11):2349-57.

12. Allen JP, Litten RZ, Fertig JB, Babor T. A review of research on the Alcohol Use Disorders Identification Test (AUDIT). Alcoholism: clinical and experimental research. 1997 Jun;21(4):613-9.

13. Gaziano TA. Cardiovascular disease in the developing world and its cost-effective management. Circulation. 2005 Dec 6;112(23):3547-53.

14. Reddy KS, Yusuf S. Emerging epidemic of cardiovascular disease in developing countries. Circulation. 1998 Feb 17;97(6):596-601.

15. Nag T, Ghosh A. Cardiovascular disease risk factors in Asian Indian population: A systematic review. Journal of cardiovascular disease research. 2013 Dec $1 ; 4(4): 222-8$.

16. Sorlie PD, Backlund E, Keller JB. US mortality by economic, demographic, and social characteristics: the National Longitudinal Mortality Study. American Journal of Public Health. 1995 Jul;85(7):949-56

17. Kaplan GA, Keil JE. Socioeconomic factors and cardiovascular disease: a review of the literature. Circulation. 1993 Oct;88(4):1973-98.

18. Chadha SL, Radhakrishnan S, Ramachandran K, Kaul U, Gopinath N. Epidemiological study of coronary heart disease in urban population of Delhi. The Indian journal of medical research. $1990 \mathrm{Dec}$ 1;92:424-30.
19. Rastogi T, Reddy KS, Vaz M, Spiegelman D, Prabhakaran D, Willett WC, Stampfer MJ, Ascherio A. Diet and risk of ischemic heart disease in India. The American journal of clinical nutrition. 2004 Apr 1;79(4):582-92.

20. Xavier D, Pais P, Devereaux PJ, Xie C, Prabhakaran D, Reddy KS, Gupta R, Joshi P, Kerkar P, Thanikachalam S, Haridas KK. Treatment and outcomes of acute coronary syndromes in India (CREATE): a prospective analysis of registry data. The Lancet. 2008 Apr 26;371(9622):1435-42.

21. Joshi R, Cardona M, Jyengar S, Sukumar A, Raju CR, Raju KR, Raju K, Reddy KS, Lopez A, Neal B. Chronic diseases now a leading cause of death in rural India-mortality data from the Andhra Pradesh Rural Health Initiative. International journal of epidemiology. 2006 Dec 1;35(6):1522-9.

22. Reddy KS, Prabhakaran D, Jeemon P, Thankappan KR, Joshi P, Chaturvedi V, Ramakrishnan L, Ahmed F. Educational status and cardiovascular risk profile in Indians. Proceedings of the National Academy of Sciences. 2007 Oct 9;104(41):16263-8.

23. Jeemon P, Reddy KS. Social determinants of cardiovascular disease outcomes in Indians. The Indian journal of medical research. 2010 Nov; 132(5):617.

24. Bhopal R, Hayes L, White M, Unwin N, Harland J, Ayis S, Alberti G. Ethnic and socio-economic inequalities in coronary heart disease, diabetes and risk factors in Europeans and South Asians. Journal of Public Health. 2002 Jun 1;24(2):95-105.

25. Moodie R, Stuckler D, Monteiro C, Sheron N, Neal B, Thamarangsi T, Lincoln P, Casswell S, Lancet NCD Action Group. Profits and pandemics: prevention of harmful effects of tobacco, alcohol, and ultra-processed food and drink industries. The lancet. 2013 Feb 23;381(9867):670-9.

26. Mendis S, Puska P, Norrving B, World Health Organization. Global atlas on cardiovascular disease prevention and control. World Health Organization; 2011.

27. Wilkinson M, Giles A, Armour JA, Cardinal R. Ventricular, but not atrial, M2-muscarinic receptors increase in the canine pacing-overdrive model of heart failure. The Canadian journal of cardiology. 1996 Jan 1;12(1):71-6

28. Mohan V, Shanthirani S, Deepa R, Premalatha G, Sastry NG, Saroja R. Intra-urban differences in the prevalence of the metabolic syndrome in southern 
India-the Chennai Urban Population Study (CUPS No. 4). Diabetic Medicine. 2001 Apr;18(4):280-7.

29. Feinstein A, Feinstein K, Gray T, O’Connor P. Prevalence and neurobehavioral correlates of pathological laughing and crying in multiple sclerosis. Archives of neurology. 1997 Sep 1;54(9):1116-21.

30. Pickett KE, James OW, Wilkinson RG. Income inequality and the prevalence of mental illness: a preliminary international analysis. Journal of Epidemiology \& Community Health. $2006 \mathrm{Jul}$ 1;60(7):646-7.

31. Biggs B, King L, Basu S, Stuckler D. Is wealthier always healthier? The impact of national income level, inequality, and poverty on public health in Latin America. Social science \& medicine. 2010 Jul 1;71(2):266-73.

32. Whithead M, Dahlgren G, Evans T. Equity and health sector reforms: can low-income countries escape the medical poverty trap. Lancet. 2001;358:833-36
33. Gwatkin DR, Guillot M, Heuveline P. The burden of disease among the global poor. The Lancet. 1999 Aug 14;354(9178):586-9.

34. Brannon L, Feist J, Updegraff JA. Health psychology: An introduction to behavior and health. Nelson Education; 2013 Feb 22.

35. Siervo M, Wells JC, Cizza G. The contribution of psychosocial stress to the obesity epidemic: an evolutionary approach. Hormone and metabolic research $=$ Hormon-und Stoffwechselforschung= Hormones et metabolisme. 2009 Apr;41(4):261.

36. Capuron L, Poitou C, Machaux-Tholliez D, Frochot V, Bouillot JL, Basdevant A, Layé S, Clément K. Relationship between adiposity, emotional status and eating behaviour in obese women: role of inflammation. Psychological medicine. 2011 Jul;41(7):1517-28.

37. Black PH. The inflammatory consequences of psychologic stress: relationship to insulin resistance, obesity, atherosclerosis and diabetes mellitus, type II. Medical hypotheses. 2006 Jan 1;67(4):879-91. 